\title{
ANALISIS KESALAHAN MATEMATIS MAHASISWA TEKNIK SIPIL PADA MATA KULIAH KALKULUS II
}

\author{
Zukhrufurrohmah $^{1}$, Adi Slamet Kusumawardana ${ }^{2}$ \\ ${ }^{1,2}$ Universitas Muhammadiyah Malang \\ Corresponding Author: zukbrufuroobmah@umm.ac.id"
}

\begin{abstract}
This research's purpose is to describe the mathematical errors of civil engineer college students in subject Calculus II. The research's method uses a qualitative approach that are reducing data, serving data, and conclude. Based on the research, it found that the major error to solve the problems of Calculus II is manipulating algebra form. The error of calculating is the second one after the error of manipulating algebra form. The researcher also finds that even the college students choose the right formula to solve the problems, they make an error in implementing the formula that they were chosen.
\end{abstract}

Keywords: mathematical errors, calclus, civil engineering.

How to cite: Zukhrufurrohmah, Z. \& Kusumawardana, A. S. (2019). Analisis Kesalahan Matematis Mahasiswa Teknik Sipil pada Mata Kuliah Kalkulus II. JRPM (Jurnal Review Pembelajaran Matematika), 4(1), 110 .

\section{PENDAHULUAN}

Penyusunan rencana kegiatan pembelajaran perlu memperhatikan beberapa aspek seperti minat, motivasi dan kemampuan awal setiap mahasiswa. Perbedaan kegiatan pembelajaran antara kelas satu dan yang lainnya didasarkan pada aspek mayoritas seperti pengalaman belajar, adat, atau budaya kelas, dominasi gender dan hal kecil lainnya (Arends, 2009). Berbagai aspek ini akan mempengaruhi bagaimana mahasiswa merespon informasi yang diberikan dan melaksanakan kegiatan belajar.

Hasil belajar dapat menjadi salah satu aspek peninjau keberhasilan kegiatan pembelajaran yang dirancang. Kurang baiknya hasil pembelajaran yang dilakukan menampakkan bahwa ada beberapa hal yang perlu diperbaiki, baik dari segi penugasan, pelaksanaan kegiatan pembelajaran, hingga evaluasi pembelajaran. Hasil belajar yang masih rendah dapat disebabkan oleh kegiatan pembelajaran yang kurang inovatif dan kurang memberi kesempatan mahasiswa menyelesaikan masalah (Paradesa, Zulkardi, \& Darmawijoyo, 2010). Kurang baiknya hasil belajar mahasiswa yang ditunjukkan melalui hasil tes dapat pula dipengaruhi oleh kesulitan belajar yang mereka alami (Rahman, Nursalam, \& Tahir, 2015). Kesulitan belajar ini dapat disebabkan oleh minat belajar dan motivasi belajar yang rendah (Mutakin, 2013), kemampuan dasar matematis yang rendah (Nugraheni, 2017). Pada mata kuliah Kalkulus Dasar, hambatan yang dialami mahasiswa pada umumnya 
terletak pada kemampuan mengoperasikan fungsi aljabar dan fungsi limit (Wahyuni, 2017).

Mata kuliah Kalkulus II merupakan mata kuliah wajib yang harus ditempuh mahasiswa Jurusan Teknik Sipil pada semester kedua tahun pertama. Mata kuliah ini merupakan kelanjutan dari matakuliah sebelumnya yaitu Kalkulus I. Mata kuliah ini mempelajari tentang fungsi, turunan dua atau lebih variabel, integral lipat dengan lebih dari dua variabel, grafik fungsi dengan fungsi dua atau lebih variabel dan aplikasi turunan dan integral dalam menyelesaikan permasalahan.

Mahasiswa perlu memiliki kemampuan dalam mengoperasikan fungsi, menentukan turunan dan integral dari fungsi dengan lebih dari dua variabel, dan menggambar peta kontur pada mata kuliah Kalkulus II. Namun, hasil tes pada mata kuliah Kalkulus II menunjukkan adanya kesulitan belajar pada mata kuliah Kalkulus II. Oleh karena hal tersebut, penelitian ini bertujuan untuk menemukan dan mendeskripsikan kesalahankesalahan mahasiswa dalam menyelesaikan soal pada mata kuliah Kalkulus II.

Kesalahan mahasiswa dalam menyelesaikan soal dapat dikategorikan menjadi kesalahan konsep, yaitu kesalahan dalam menyimpulkan suatu hal berdasar ciri yang diidentifikasi (Sumiati \& Asra, 2009). Kesalahan dalam menyelesaikan permasalahan dapat pula disebabkan oleh kesalahan menggunakan data, kesalahan interpretasi bahasa, kesalahan teknis dan kesalahan penarikan kesimpulan (Fatimah, 2013). Jenis-jenis kesalahan matematis yang dilakukan mahasiswa dapat dianalisis dengan menggunakan beberapa metode atau prosedur. Analisis kesalahan dapat dilakukan dengan prosedur Newman's Error Analysis (NEA) yang memuat kerangka kerja untuk mendiagnostik kesalahan yang terdiri dari decoding, comprehension, transformation, process skill, dan encoding (Utami, 2016). Kesalahan mahasiswa dalam menyelesaikan soal trigonometri dan kalkulus I meliputi kesalahan fakta, keselahan keterampilan, kesalahan konsep dan kesalahan prinsip (Abidin, 2012). Amir (2015) menyatakan bahwa kesalahan dalam menyelesaikan soal pertidaksamaan linier meliputi kesalahan konsep, kesalahan fakta, kesalahan operasi, dan kesalahan prinsip.

Berdasar berbagai pendapat peneliti lain mengenai jenis kesalahan matematis dalam menyelesaikan soal matematika, peneliti menetapkan 3 aspek yang akan dianalisis. Aspek kesalahan matematis pada penelitian ini meliputi kesalahan keterampilan, kesalahan konsep dan kesalahan teknik. Indikator kesalahan keterampilan meliputi tidak menyelesaikan soal dengan cepat dan runtun, tidak menyelesaikan ide atau pekerjaan hingga selesai, dan kesalahan memilih teorema atau rumus yang tepat untuk menyelesaikan masalah. Indikator kesalahan konsep dilihat melalui kesalahan mahasiswa mengaplikasi konsep atau teorema 
yang dipilih untuk menyelesaikan soal. Sedangkan indikator kesalahan teknik meliputi kesalahan melakukan manipulasi aljabar dan kesalahan melakukan perhitungan atau komputasi.

\section{METODE PENELITIAN}

Jenis penelitian ini adalah penelitian deskriptif kualitatif. Data deskriptif digunakan untuk mendeskripsikan kesalahan-kesalahan mahasiswa teknik sipil dalam menyelesaikan soal pada mata kuliah Kalkulus II. Data kuantitatif digunakan untuk menyajikan persentase jenis kesalahan yang dilakukan mahasiswa. Sasaran penelitian ini adalah mahasiswa semester genap tahun akademik 2017/2018 jurusan Teknik Sipil sejumlah 41 mahasiswa. Penelitian dilaksanakan di salah satu universitas swasta di Kota Malang.

Instrumen penelitian yang digunakan adalah lembar tes yang mencakup indikator menyelesaikan masalah terkait integral lipat dua, menyelesaikan masalah terkait konsep integral mengenai pusat massa, dan menyelesaikan masalah menggunakan integral lipat tiga. Jumlah soal tes yang diberikan adalah 3 butir soal. Soal yang diberikan dapat dilihat pada Tabel 1 di bawah ini. Selain lembar tes, digunakan lembar indikator kesalahan matematis. Instrumen ini berdasar kriteria aspek kesalahan yang telah ditentukan peneliti, yaitu kesalahan keterampilan, kesalahan konsep dan kesalahan teknik.

Tabel 1. Bentuk Soal Tes dan Indikator Setiap Soal

\begin{tabular}{|c|c|c|}
\hline No & Indikator & Bentuk Soal \\
\hline 1. & $\begin{array}{l}\text { Menyelesaikan masalah menggunakan } \\
\text { integral lipat dua }\end{array}$ & $\begin{array}{l}\text { Hitung integral lipat dua berikut: } \\
\qquad \int_{0}^{\mathrm{a}} \int_{0}^{1} 2 x \sqrt{x^{2}+y} d x d y\end{array}$ \\
\hline 2. & $\begin{array}{l}\text { Menyelesaikan masalah terkait konsep } \\
\text { integral mengenai pusat massa }\end{array}$ & $\begin{array}{l}\text { Carilah massa dan pusat massa }(\bar{x}, \bar{y}) \text { dari lamina } \\
\text { yang dibatasi oleh kurva dan fungsi kerapatan } \\
\text { berikut: } \\
\qquad y=\frac{1}{x}, y=x, y=0, x=2 ; \delta(x, y)=x\end{array}$ \\
\hline 3. & $\begin{array}{l}\text { Menyelesaikan masalah menggunakan } \\
\text { integral lipat tiga }\end{array}$ & $\begin{array}{l}\text { Selesaikan integral lipat tiga berikut: } \\
\qquad \int_{0}^{2} \int_{0}^{z} \int_{0}^{\sqrt[3]{x / z}} 2 x y z d y d x d z\end{array}$ \\
\hline
\end{tabular}

Teknik pengumpulan data dilakukan melalui tes tulis berupa soal essai dan dokumentasi. Soal tes telah divalidasi oleh 2 dosen lain yang juga memiliki pengalaman mengampu mata kuliah Kalkulus II di Jurusan Teknik Sipil. Dokumentasi dalam penelitian ini adalah semua hasil pengerjaan soal tes oleh mahasiswa Jurusan Teknik Sipil.

Pada penelitian ini dilakukan langkah reduksi data, penyajian data, dan menyimpulkan 
dalam kegiatan analisis data. Pada kegiatan reduksi data, peneliti memilih hasil pekerjaan mahasiswa yang sesuai dengan kebutuhan yaitu mendeskripsikan kesalahan matematis mahasiswa dalam menyelesaikan soal. Kemudian dilanjutkan dengan menyajikan data dengan menyusun data berdasar jenis kesalahan matematis yang muncul. Hasil analisis jenis kesalahan matematis mahasiswa kemudian simpulkan.

\section{HASIL DAN PEMBAHASAN}

Jumlah kesalahan matematis mahasiswa (dalam persen) berdasar hasil pengerjaan soal yang diberikan berdasar indikator yang telah ditetapkan disajikan pada Tabel 2 di bawah ini.

Tabel 2. Persentase Kesalahan Matematis Mahasiswa Tiap Indikator

\begin{tabular}{|c|c|c|c|c|c|}
\hline \multirow{2}{*}{ No } & \multirow{2}{*}{ Indikator } & \multicolumn{3}{|c|}{ Nomor Soal } & \multirow{2}{*}{ Rerata } \\
\hline & & 1 & 2 & 3 & \\
\hline 1 & Tidak Menyelesaikan soal dengan cepat dan runtun & 26.8 & 68.3 & 22.0 & 39.0 \\
\hline 2 & Tidak menyelesaikan ide/pekerjaan hingga selesai & 14.6 & 70.7 & 22.0 & 35.8 \\
\hline 3 & $\begin{array}{l}\text { Kesalahan memilih teorema / rumus yang tepat untuk } \\
\text { menyelesaikan soal }\end{array}$ & 31.7 & 48.8 & 17.1 & 32.5 \\
\hline 4 & $\begin{array}{l}\text { Kesalahan mengaplikasikan konsep yang dipilih untuk } \\
\text { menyelesaikan soal }\end{array}$ & 82.9 & 73.2 & 51.2 & 69.1 \\
\hline 5 & Salah melakukan manipulasi aljabar dengan tepat & 95.1 & 80.5 & 92.7 & 89.4 \\
\hline 6 & $\begin{array}{l}\text { Salah melakukan perhitungan atau komputasi dengan } \\
\text { tepat }\end{array}$ & 75.6 & 75.6 & 80.5 & 77.2 \\
\hline
\end{tabular}

Data yang disajikan pada Tabel 2, menunjukkan bahwa kesalahan matematis terbanyak yang dilakukan mahasiswa dalam menyelesaikan soal adalah kesalahan dalam memanipulasi aljabar. Kesalahan terbanyak kedua ada pada kesalahan melakukan perhitungan atau komputasi dengan tepat pada nomor soal 2 dan 3. Pada nomor soal 1, kesalahan terbanyak kedua ada pada indikator kesalahan mengaplikasikan konsep yang dipilih untuk menyelesaikan soal.

Pada hasil pengerjaan siswa tampak bahwa kesalahan melakukan manipulasi aljabar dilakukan mahasiswa dalam merubah bentuk akar menjadi bentuk pangkat dan mengoperasikan bentuk pangkat. Hal ini sejalan dengan hasil penelitian Mutakin (2013) bahwa penyebab kesulitan siswa dalam mengikuti pelajaran kalkulus adalah kurang mampu dalam mengoperasikan suku sejenis pecahan, kurang mampu dalam operasi pecahan campuran, dan kurang mampu dalam operasi penjumlahan fungsi. Pada materi geometri, mahasiswa juga melakukan kesalahan dalam memanipulasi aljabar sehingga proses transformasi yang dilakukan juga kurang tepat (Utami, 2016). Kesalahan melakukan manipulasi aljabar juga dilakukan mahasiswa dalam menentukan apakah suatu himpunan 
termasuk group atau bukan (Fatimah, 2013).

Selain kesalahan memanipulasi bentuk aljabar, tingkat kesalahan dalam melakukan perhitungan atau komputasi juga dapat dikatakan tinggi mengingat rerata persentase kesalahan ini bernilai 77,2\%. Kesalahan komputasi pada hasil penelitian ini didominasi pada kesalahan operasi menghitung bilangan berpangkat dan pecahan. Hal ini sejalan dengan penelitian Isgiyanto (2011) yang menemukan kesalahan hitung dalam pengerjaan soal yang dilihat dari tidak dapat melakukan komputasi dengan benar, tidak dapat menerapkan operasi hitung atau operasi aljabar dengan tepat dan tidak dapat melakukan perhitungan dengan cermat.

Berdasar persentase kesalahan matematis yang telah disajikan pada Tabel 1, dapat dikatakan bahwa sebagian besar mahasiswa telah memilih teorema dengan benar. Hal ini ditunjukkan dengan rerata persentase kesalahan memilih teorema atau rumus yang tepat untuk menyelesaikan masalah sebesar 32,5\%. Dengan kata lain 67,5\% mahasiswa memilih teorema atau rumus yang tepat dapam menyelesaikan soal. Namun, meski benar memilih teorema, 69,1\% mahasiswa melakukan kesalahan dalam mengaplikasikan konsep yang dipilih untuk menyelesaikan soal, sehingga berdampak pada kesalahan malakukan manipulasi aljabar dan kesalahan komputasi.

Gambar 1 berikut menunjukkan kesalahan matematis yang dilakukan mahasiswa ada indikator tidak menyelesaikan soal dengan cepat dan runtun.

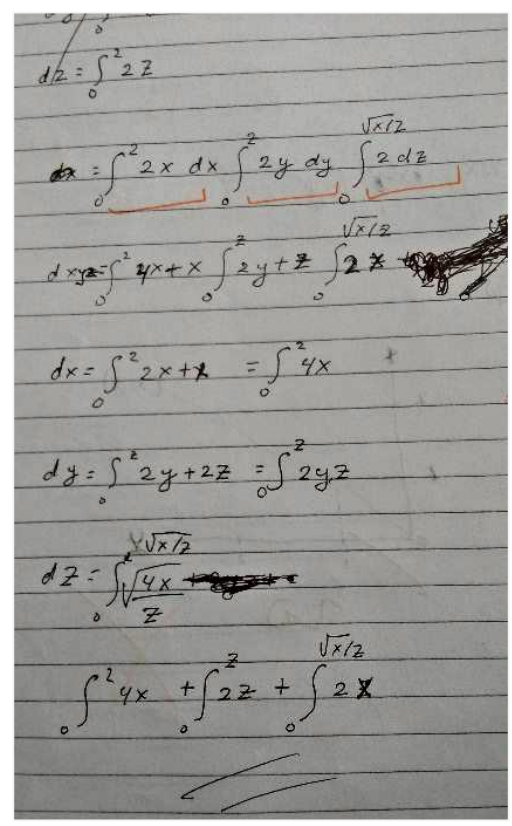

Gambar 1. Indikator Tidak Menyelesaikan Soal dengan Cepat dan Runtun

Gambar 1 di atas juga menunjukkan kesalahan mahasiswa dalam memilih 
rumus/teorema yang digunakan dalam menyelesaikan soal yang diberikan. Mahasiswa memisahkan integral pertama, kedua dan ketiga beserta fungsinya yang seharusnya fungsi tidak dipisahkan.

Indikator tidak menyelesaikan ide/pekerjaan hingga selesai ditunjukkan pada Gambar 2 di bawah ini. Pada contoh pada Gambar 2 terlihat bahwa mahasiswa tidak menyelesaikan proses pengintegralan dan tampak bahwa sedari awal proses integral, mahasiswa juga melakukan kesalahan dalam mengaplikasikan konsep yang dipilih untuk menyelesaikan soal.

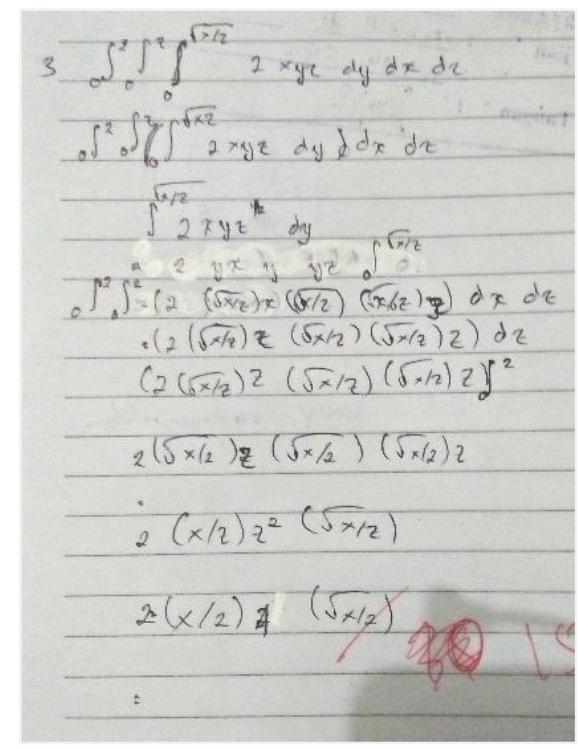

Gambar 2. Indikator Tidak Menyelesaikan Pekerjaan Hingga Selesai

Kesalahan memilih teorema atau rumus yang tepat dalam menyelesaikan soal disajikan pada Gambar 3 di bawah ini. Berdasar Gambar 3 dapat dilihat bahwa mahasiswa masih bingung dalam menggunakan konsep integral atau turunan ketika berhadapan dengan operasi perkalian fungsi. Pada Gambar tampak bahwa mahasiswa menuliskan rumus perkalian turunan fungsi $(u \cdot v)^{\prime}=u^{\prime} v+u v^{\prime}$ kemudian mengaplikasikannya menjadi $\int(u \times v)=\int u d u \times v+u \times \int v d v$ (hasil perhitungan ini ditandai dengan kotak jingga pda gambar).

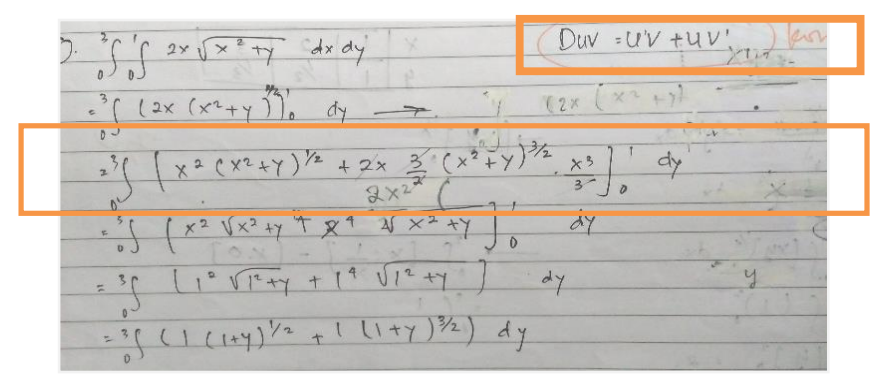

Gambar 3. Indikator Kesalahan Memilih Teorema atau Rumus yang Tepat untuk Menyelesaikan Soal 
Meski benar memilih metode yang digunakan, mahasiswa dapat melakukan kesalahan dalam mengaplikasikan konsep yang dipilih untuk menyelesaikan soal tersebut. Gambar 4 di bawah ini menunjukkan hasil jawaban mahasiswa yang melakukan kesalahan tersebut. Mahasiswa benar memilih konsep untuk menyelesaikan soal nomor 2 yaitu dengan mencari posisi $x$ terlebih dahulu untuk mendapatkan titi pusat masa. Namun mahasiswa melakukan kesalahan hingga hasil yang diperoleh tidak sesuai dengan yang seharusnya.

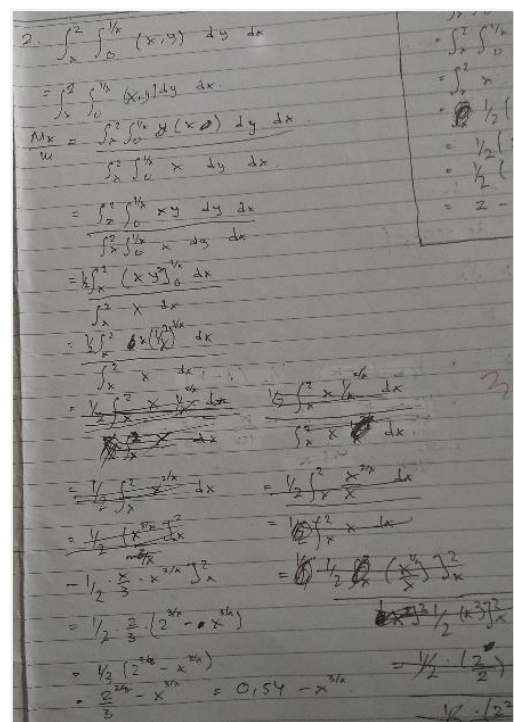

Gambar 4. Indikator Kesalahan Mengaplikasikan Konsep yang Dipilih untuk Menyelesaikan Soal

Kesalahan melakukan manipulasi aljabar ditunjukkan pada Gambar 5 di bawah ini. Berdasar gambar tampak bahwa mahasiswa tidak melakukan sesalahan pada pemilihan teorema atau rumus dan tidak melakukan kesalahan dalam mengaplikasikan konsep integral. Namun, pada langkah selanjutnya, mahasiswa melakukan kesalahan dalam memanipulasi aljabar yaitu mensubstitusi $\frac{\sqrt{x}}{z}$.

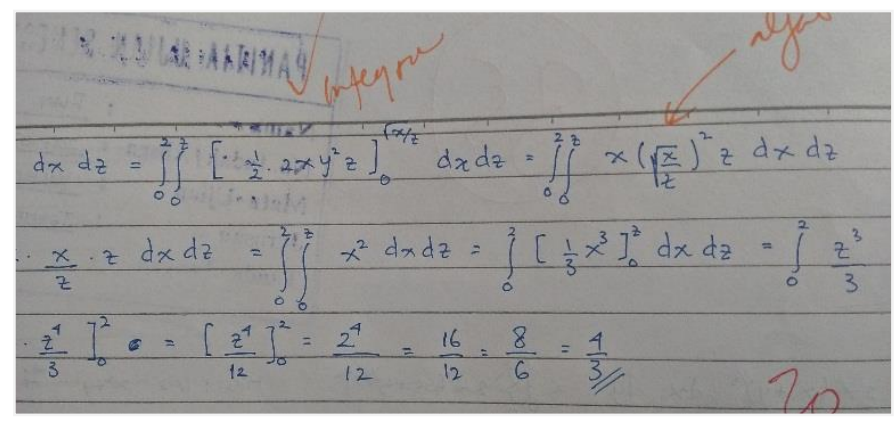

Gambar 5. Indikator Memanipulasi Bentuk Aljabar 
Kesalahan matematis dalam melakukan perhitungan atau komputasi berada pada urutan kedua terbesar setelah kesalahan memanipulasi bentuk aljabar. Contoh kesalahan matematis dalam melakukan perhitungan atau komputasi ditunjukkan pada Gambar 6 di bawah. Berdasarkan Gambar 6 tampak bahwa mahasiswa melakukan kesalahan dalam menghitung penjumlahan bentuk pecahan.

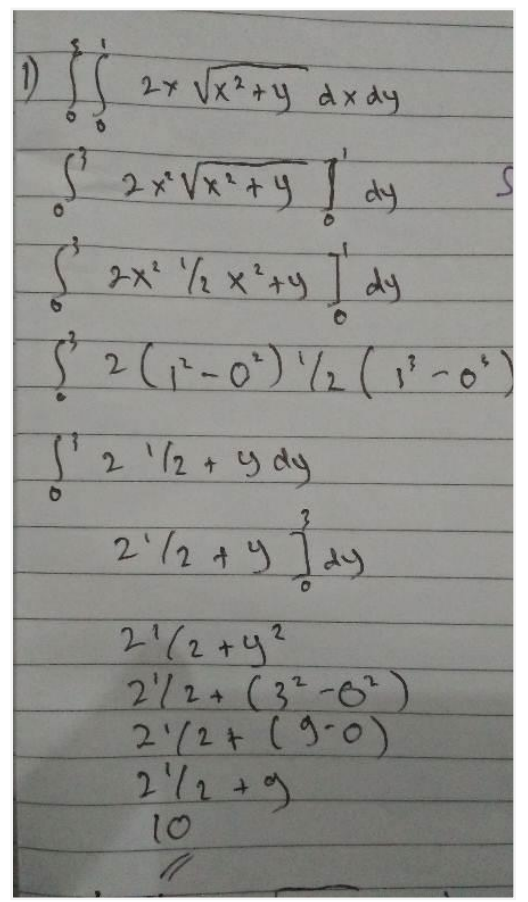

Gambar 6. Indikator Melakukan Kesalahan Komputasi Atau Perhitungan

\section{SIMPULAN DAN SARAN}

Temuan penelitian menunjukkan bahwa kesalahan yang dominan dilakukan mahasiswa dalam menyelesaikan soal pada mata kuliah Kalkulus II adalah kesalahan memanipulasi aljabar. Kesalahan terbesar kedua adalah kesalahan melakukan perhitungan atau komputasi. Kesalahan memilih rumus atau teorema yang digunakan jarang dilakukan mahasiswa namun pemilihan rumus atau teorema yang tepat tidak menjamin mahasiswa benar dalam mengaplikasikan teorema atau rumus tersebut. Hal ini tampak pada rerata persentase kesalahan menerapkan teorema atau rumus yang digunakan untuk menyelesaikan soal lebih tinggi dibandingkan rerata kesalahan memilih teorema atau rumus yang digunakan.

Penelitian ini memfokuskan pada kesalahan mahasiswa pada hasi pengerjaan soal mata kuliah Kalkulus II. Penelitian selanjutnya dapat membahas mengenai cara berpikir 
mahasiswa dalam menyelesaikan soal yang diberikan sehingga dapat dilakukan solusi yang tepat untuk mengurangi kesalahan yang dilakukan mahasiswa dalam menyelesaikan soal soal yang ada pada matakuliah Kalkulus II dan mata kuliah lainnya. Berdasar temuan penelitian, kesalahan manipulasi aljabar yang dilakukan mahasiswa terletak pada mengubah dan mengoperasikan aljabar berbentuk akar atau pangkat pecahan. Oleh karena hal tersebut, sebaiknya kegiatan pembelajaran di luar kelas ditambahkan dengan latihan soal atau penanaman konsep tentang operasi bentuk aljabar atau manipulasi aljabar. Alternatif lain yang dapat digunakan adalah meminimalisir kesalahan pengerjaan soal adalah membuat modul atau lembar kegiatan mahasiswa berdasar pada jenis kesalahan yang ada.

\section{DAFTAR RUJUKAN}

Abidin, Z. (2012). Analisis Kesalahan Mahasiswa Prodi Pendidikan Matematika Fakultas Tarbiyah IAIN Ar-Ranity dalam Mata Kuliah Trigonometri dan Kalkulus 1. Jurnal Ilmiah DIDAKTIKA, 13(1), 183-196. DOI: http://dx.doi.org/10.22373/jid.v13i1.472.

Amir, M. F. (2015). Analisis Kesalahan Mahasiswa PGSD Universitas Muhammadiyah Sidoarjo dalam Menyelesaikan Soal Pertaksamaan Linier. Jurnal Edukasi, 1(2), 131145. Retrieved from http://jurnal.stkippgrisidoarjo.ac.id/index.php/je/article/view/20.

Arends, R. I. (2009). Learning to Teach. United States: Mc Graw Hill.

Fatimah, F. (2013). Deskripsi Kesalhaan Mahasiswa dalam Membuktikan Suatu Group (Studi Pada Mahasiswa pendidikan Matematika Universitas Al Asyariah Mandar). Jurnal Pepatuzdu, 5(1), 38-47. DOI: http://dx.doi.org/10.35329/fkip.v5i1.62.

Isgiyanto, A. (2011). Diagnosa Kesalahan Siswa Berbasis Penskoran Politomus. Jurnal Penelitian dan Evaluasi Pendidikan, 15(2), 308-325. DOI: https://doi.org/10.21831/pep.v15i2.1099.

Mutakin, T. Z. (2013). Analisis Kesulitan Belajar Kalkulus 1 mahasiswa Teknik Informatika. Jurnal Formatif, 3(1), 49-60. DOI: http://dx.doi.org/10.30998/formatif.v3i1.113

Nugraheni, D. (2017). Analisis Kesulitan Belajar Mahasiswa pada Mata Kuliah Mekanika. EduSains: Jurnal Pendidikan Sains dan Matematika, 5(1), 23-32. DOI: https://doi.org/10.23971/eds.v5i1.586.

Paradesa, R., Zulkardi, \& Darmawijoyo. (2010). Bahan Ajar Kalkulus 2 Menggunakan Macromedia Flash dan Maple di STKIP PGRI Lubuklinggau. Jurnal Pendidikan Matematika, 4(1), 95-109. DOI: https://doi.org/10.22342/jpm.4.1.314.

Rahman, U., Nursalam, \& Tahir, M. R. (2015). Pengaruh Kecemasan dan Kesulitan Belajar Matematika Terhadap hasil Belajar Matematika pada Siswa Kelas X MA Negeri 1 
Watampone Kabupaten Bone. Jurnal Matematika dan Pembelajaran (MaPan), 3(1), 85102. DOI: https://doi.org/10.24252/mapan.2015v3n1a8.

Sumiati \& Asra. (2009). Metode Pembelajaran. Bandung: CV Wacana Prima.

Utami, A. D. (2016). Kesalahan Mahasiswa dalam Menyelesaikan Materi Berdasar Newman's Error Analysis (NEA). Jurnal Ilmiah Pendidikan Matematika, 4(2), 85-92. DOI: http://doi.org/10.25273/jipm.v4i2.842.

Wahyuni, A. (2017). Analisis Hambatan Belajar Mahasiswa pada Mata Kuliah Kalkulus Dasar. JNPM Jurnal Nasional Pendidikan Matematika), 1(1), 10-23. DOI: http://dx.doi.org/10.33603/jnpm.v1i1.253. 